Revista Iberoamericana de Micología

Original article

\title{
Pigeons and their droppings as reservoirs of Candida and other zoonotic yeasts
}

Inmaculada Rosario Medina, Lorena Román Fuentes, Miguel Batista Arteaga, Fernando Real Valcárcel, Félix Acosta Arbelo, Daniel Padilla del Castillo, Soraya Déniz Suárez, Otilia Ferrer Quintana, Belinda Vega Gutiérrez, Freddy Silva Sergent, Begoña Acosta-Hernández*

Instituto Universitario de Sanidad Animal y Seguridad Alimentaria (IUSA), Universidad de Las Palmas de Gran Canaria, Las Palmas, Spain

\section{A R T I C L E I N F O}

\section{Article history:}

Received 9 November 2016

Accepted 9 March 2017

Available online 15 July 2017

\section{Keywords:}

Columba livia

Pigeons

Candida

Yeasts

Zoonotic yeasts

\begin{abstract}
A B S T R A C T
Background: The importance of pigeons as reservoirs and carriers of Cryptococcus neoformans and other species of this genus is well-known; however, less is known about their role as reservoirs and carriers of other yeasts that impact public health.

Aims: The present study was performed on Gran Canaria Island to define yeasts other than Cryptococcus spp. that have been reported to impact public health and which could be carried by pigeons.

Methods: Samples were obtained from 83 pigeon lofts (Columba livia); moreover, 331 crop samples, 331 cloacal samples and 174 dropping samples were collected. In addition, 17 dropping samples were taken from a total of 17 public squares. Samples were inoculated on Sabouraud dextrose agar with chloramphenicol.

Results: Different yeast species, i.e. Candida guilliermondii (24.36\%), Candida kefyr (1.21\%), Saccharomyces cerevisiae (2.43\%), and Trichosporon asahii (1.21\%) were isolated for the first time from the cloaca. The most frequently isolated yeast from the crop, cloaca and dropping samples from lofts was C. guilliermondii (30.46\%, 24.36\% and 49.37\%, respectively). In addition, for the first time, C. kefyr (3.65\%), Candida pelliculosa (2.43\%), Candida rugosa (1.21\%), T. asahii (3.65\%), Trichosporon mucoides (3.65\%) and Prototheca wickerhamii (1.21\%) were obtained from crop samples; Candida pelliculosa (1.20\%), T. asahii (9.63\%) and T. mucoides (7.22\%) were isolated from dropping samples in the lofts. Candida albicans was the most frequently isolated yeast in dropping samples collected in public squares.

Conclusions: It can be assumed that pigeons and their droppings act as carriers and reservoirs of Candida spp. and other zoonotic yeasts.
\end{abstract}

C 2017 Asociación Española de Micología. Published by Elsevier España, S.L.U. All rights reserved.

\section{La paloma y sus excrementos como reservorios de Candida y otras levaduras zoonóticas}

\section{R E S U M E N}

Antecedentes: Es bien conocido el papel que desempeña la paloma como reservorio y portadora de Cryptococcus neoformans y otras especies del género; sin embargo, se conoce poco sobre el papel que desempeña como reservorio y portadora de otras levaduras que repercuten en la salud pública.

Objetivos: El presente estudio fue realizado en la isla de Gran Canaria para determinar otras levaduras diferentes del género Cryptococcus que podrían portar las palomas y que repercuten en la salud pública. Métodos: Se tomaron muestras en 83 palomares (Columba livia): 331 muestras de buche, 331 cloacales y 174 muestras de excrementos. También se tomaron 17 muestras de excrementos en 17 plazas públicas. Las distintas muestras se sembraron en agar glucosado de Sabouraud con cloranfenicol.

\footnotetext{
* Corresponding author.

E-mail address: bego.acosta@ulpgc.es (B. Acosta-Hernández).
} 
Resultados: Se aislaron por primera vez de la cloaca diferentes especies de levaduras: Candida guilliermondii (24,36\%), Candida kefyr (1,21\%), Saccharomyces cerevisiae (2,43\%), Trichosporon asahii $(1,21 \%)$. La levadura más frecuentemente aislada de muestras de buche, cloaca y heces de palomares fue $C$. guilliermondii $(30,46,24,36$ y 49,37\%, respectivamente). A estas especies se suman otras aisladas por primera vez a partir de muestras de buche: C. kefyr (3,65\%), Candida pelliculosa (2,43\%), Candida rugosa (1,21\%), T. asahii (3,65\%), Trichosporon mucoides $(3,65 \%)$ y Prototheca wickerhamii $(1,21 \%)$. Se aislaron por primera vez de muestras de excrementos de palomares las especies C. pelliculosa (1,20\%), T. asahii $(9,63 \%)$ y $T$. mucoides (7,22\%). Candida albicans fue la levadura más frecuentemente aislada de muestras de heces recogidas de plazas públicas.

Conclusiones: Por todo ello, concluimos que la paloma y sus excrementos actúan como portadores y reservorios de especies de Candida y otras levaduras zoonóticas.

(C) 2017 Asociación Española de Micología. Publicado por Elsevier España, S.L.U. Todos los derechos reservados.

The role of pigeons and other birds as carriers of various important public health pathogens such as protozoa, fungi, bacteria and viruses is well-known. ${ }^{5}$ Pigeons and other birds play an important role in public health as carriers of Cryptococcus species, ${ }^{21-23}$ especially Cryptococcus neoformans. ${ }^{6}$ However, Cryptococcus is not the only yeast genus that impacts human public health, as there is currently a boom in pathologies involving other yeasts, especially Candida species. ${ }^{25}$ In fact, the newly emerging human pathogenic yeast species include Malassezia furfur, Trichosporon asahii, species of Rhodotorula, Wickerhamomyces anomalus and different species of Candida such as Candida albicans. To a lesser extent, Candida lusitaniae, Candida holmii, Candida norvegensis, Candida valida and Candida dubliniensis appear to be of importance in public health. ${ }^{4,31}$ Similarly, other agents that have previously been considered environmental pollutants or of industrial importance, such as Candida utilis and Candida lipolytica, are currently identified as agents of fungemia, onychomycosis and systemic disease. ${ }^{7}$ For this reason, it is important to study the different yeast strains obtained from pigeon samples (crop, cloaca, droppings). The aim of this work was to define which genera of yeasts, other than Cryptococcus, could be carried by pigeons and their droppings.

\section{Materials and methods}

Sampling was performed in 83 pigeon lofts from 17 pigeonbreeding associations distributed throughout Gran Canaria Island (Spain). For this study, 331 samples from the crop and cloaca and 174 samples of pigeon droppings were analyzed. In addition, we also sampled 17 public squares, and a mixture of pigeon droppings from each park was taken.

Samples of the cloaca and crop were collected from 331 pigeons using sterile cotton swabs in a transport medium (Eurotubo ${ }^{\circledR}$, Rubi, Barcelona, Spain). The swab was introduced and rotated in the cloaca after cleaning the area with antiseptic iodine solution (10\%). For crop sampling, pigeons were restrained and after gently opening the beak of the pigeon, one swab was introduced into the crop. All samples were stored and kept at $4{ }^{\circ} \mathrm{C}$ until further processing in the laboratory. Dropping samples from public squares and pigeon lofts were collected using sterile wooden spatulas and then kept in sterile vials at $4{ }^{\circ} \mathrm{C}$ until further processing.

Fecal samples $(2 \mathrm{~g})$ were diluted in sterile saline solution $(10 \mathrm{ml})$, homogenized by shaking and allowed to settle for $30 \mathrm{~min}$. Then, $0.5 \mathrm{ml}$ aliquots of each supernatant were used for inoculation on laboratory media agar. All samples (crop, cloaca and feces) were inoculated on Sabouraud dextrose agar and malt agar; chloramphenicol $(50 \mathrm{mg} / \mathrm{l})$ was added to the media to prevent bacterial growth. Plates were incubated at $30^{\circ} \mathrm{C}$ and $37^{\circ} \mathrm{C}(1-7$ days) and inspected daily. All colonies with a microscopic morphology consistent with yeast were isolated and identified by auxanogram using
API 20C Auxanogram strips and API ID 32C Auxanogram strips (bioMérieux ${ }^{\circledR}$, Madrid, Spain).

For the strains identified as Candida spp., several complementary tests were performed. Pseudohyphae and blastoconidia production was analyzed using corn meal agar (Oxoid Limited, Basingstoke, England) with Tween 80 at a final concentration of $0.02 \%$ to reduce surface tension. The identification was performed using the technique described by Koneman et al. ${ }^{13}$ and confirmed by using the ChromID $^{\circledR}$ Candida (bioMérieux ${ }^{\circledR}$ ) and bird-seed agar. ${ }^{18}$

\section{Results}

A total of 13 different yeast species belonging to four different genera (Candida, Saccharomyces, Trichosporon, Rhodotorula) and a strain of a unicellular alga belonging to the genus Prototheca were isolated. The relative incidence of each species detected in crop, cloaca and dropping samples is compiled in Table 1.

Candida guilliermondii and Candida albicans were isolated in a significant percentage in the three sampling locations. C. guilliermondii was the most frequently isolated yeast both in crop (30.46\%) and cloaca (24.36\%) samples. Regarding the yeasts isolated in dropping samples, C. guilliermondii was also isolated the most frequently (49.37\%), followed by C. albicans (15.66\%), T. asahii (9.63\%), Rhodotorula mucilaginosa and Trichosporon mucoides (7.22\%). In contrast, Candida kefyr, Candida zeylanoides and Prototheca wickerhamii were not isolated from any dropping sample.

C. albicans was the most frequently isolated yeast in dropping samples of public squares $(29.4 \%, 5 / 17)$, followed by two other yeasts with a significant impact (Candida krusei and Candida inconspicua, 17.6\%, 3/17). The less frequently isolated were C. guilliermondii and Candida famata (11.8\%, 2/17), and finally,

Table 1

Incidence of yeast species isolated in crop, cloaca and dropping samples from pigeons.

\begin{tabular}{llll}
\hline Species & $\begin{array}{l}\text { Crop } \\
n=82(\%)\end{array}$ & $\begin{array}{l}\text { Cloaca } \\
n=82(\%)\end{array}$ & $\begin{array}{l}\text { Dropping } \\
n=83(\%)\end{array}$ \\
\hline Candida guilliermondii & $25(30.46)$ & $20(24.36)$ & $41(49.37)$ \\
Candida albicans & $11(13.41)$ & $3(3.65)$ & $13(15.66)$ \\
Candida kefyr & $3(3.65)$ & $1(1.21)$ & $0(0)$ \\
Saccharomyces cerevisiae & $3(3.65)$ & $2(2.43)$ & $1(1.20)$ \\
Trichosporon asahii & $3(3.65)$ & $1(1.21)$ & $8(9.63)$ \\
Rhodotorula mucilaginosa & $3(3.65)$ & $0(0)$ & $6(7.22)$ \\
Trichosporon mucoides & $3(3.65)$ & $0(0)$ & $6(7.22)$ \\
Candida pelliculosa & $2(2.43)$ & $0(0)$ & $1(1.20)$ \\
Candida rugosa & $1(1.21)$ & $0(0)$ & $1(1.20)$ \\
Candida zeylanoides & $1(1.21)$ & $0(0)$ & $0(0)$ \\
Rhodotorula glutinis & $1(1.21)$ & $0(0)$ & $1(1.20)$ \\
Prototheca wickerhamii & $1(1.21)$ & $0(0)$ & $0(0)$ \\
Candida parapsilosis & $0(0)$ & $0(0)$ & $1(1.20)$ \\
Candida lusitaniae & $0(0)$ & $0(0)$ & $1(1.20)$ \\
\hline
\end{tabular}


C. lusitaniae, Candida glabrata and Candida pelliculosa were detected in only one public square (5.9\%).

\section{Discussion}

The present study defines the incidence of different yeasts isolated from pigeon lofts. To our knowledge, the results show the first isolation of yeast species other than Cryptococcus spp. in pigeons from three sampling locations (crop, cloaca and dropping samples). These findings show that pigeons are a main reservoir of different species of yeasts, and this fact could be important for public health as there is currently an increase in cases of fungemia in humans. ${ }^{27}$

Few researchers have isolated fungal species from pigeon cloacas, and for this reason some of the yeast isolates in our study cannot be compared with previous studies in pigeons. Ramirez et al. ${ }^{20}$ isolated fourteen fungal species from the ilio-cecal-colic conjunction of feral pigeons (including C. albicans), similarly to our study. In 2005, Rosario et al. ${ }^{21}$ evaluated the prevalence of different yeasts (Cryptococcus genus) in samples from pigeon cloacas. Costa et al. ${ }^{1}$ reported the isolation of Candida, Trichosporon and R. mucilaginosa from cloaca samples. In the present study, several species (C. guilliermondii, C. albicans, C. kefyr, S. cerevisiae, T. asahii) were isolated for the first time from cloaca samples, although the most frequently isolated yeasts were $C$. guilliermondii and C. albicans.

The isolation of several yeast species from pigeon droppings has been previously reported. Vidotto and Gallo 28 confirmed the presence of yeasts in pigeon stool in Turin and found that the fungal load was high. They isolated similar pathogenic yeasts to our study, such as C. guilliermondii, C. albicans, C. lusitaniae, C. parapsilosis, C. rugosa and S. cerevisiae, many of which are considered pathogenic ${ }^{10}$; therefore, they concluded that the pigeon is an important carrier of pathogens for humans and pets and represents a serious health problem. Gallo et al. ${ }^{3}$ isolated a total of 25 yeast species, and six of these yeasts were also reported in our study (C. rugosa, $R$. glutinis, C. parapsilosis, S. cerevisiae, C. albicans and C. guilliermondii). Maldonado et al. ${ }^{15}$ also identified the following species: C. holmii, C. globosa, C. norvegica, C. colliculosa and Lachancea kluyveri (Saccharomyces kluyveri). Finally, R. mucilaginosa ${ }^{1}$ and Debaryomyces hansenii var. hansenii ${ }^{17}$ have also been isolated from pigeon droppings. In our study, a high number of previously reported yeasts were isolated from fecal samples; however, three yeast-like fungal isolates, T. asahii (9.3\%), C. pelliculosa (1.20\%) and T. mucoides (7.22\%), were recovered for the first time in variable percentages from pigeon droppings.

According to our results, the excreta of pigeons are an ideal environment for Candida and Trichosporon replication. We isolated yeasts from these samples that had not been previously isolated from the crop or cloaca, such as C. parapsilosis and C. lusitaniae. Pigeon feces are an ideal environment for yeast replication with an impact on public health.

In this regard, T. asahii has been isolated from humans and causes a variety of diseases. It has been found in equipment rooms and lavatories, suggesting transmission through toilets. ${ }^{2}$ T. asahii has been reported as the most frequently isolated Trichosporon species in human patients, causing invasive trichosporonosis. ${ }^{24}$ Similarly, T. mucoides, frequently isolated from cases of invasive trichosporonosis, has been identified as being responsible for onychomycosis ${ }^{26}$ and has also been associated with human fungemia. ${ }^{19}$ Different studies have confirmed that invasive trichosporonosis has emerged as an opportunistic infectious disease in immunocompromised patients, ${ }^{24}$ and there are studies associating trichosporonosis in humans with close contact with pigeons. ${ }^{16}$ Finally, C. pelliculosa was reported as causing an outbreak of fungemia in neonatal intensive care unit ${ }^{14}$ and was also found in immunocompromised pediatric patients. ${ }^{12,25}$
Similarly to our study, a high number of yeast species (C. guilliermondii, C. albicans, C. zeylanoides, S. cerevisiae, R. glutinis and $R$. mucilaginosa) were isolated from crop samples by Hermoso de Mendoza et al. ${ }^{8}$ Furthermore, in our study different yeast species, such as C. kefyr, C. pelliculosa, C. rugosa, T. asahii and T. mucoides, were isolated from crop samples, and no previous references have reported the isolation of the abovementioned yeasts in pigeons. Prototheca wickerhamii, never previously isolated from pigeons, was also recovered from crop samples, but not from cloaca samples or droppings. Therefore, we can speculate that the isolation of $P$. wickerhamii from the crop could be due to water contamination. Prototheca wickerhamii rarely causes infection in humans but is capable of producing opportunistic infections of the skin and subcutaneous tissues in humans, especially in AIDS, diabetic or immunocompromised patients. ${ }^{9,11,29,30}$

It is likely that the emergence and increase of different pathogenic yeasts is due not only to a major incidence of infection among immunocompromised hosts, but also to changes in the pathogenic features of these species of yeasts and increasing resistance to antifungal agents, in particular azoles. ${ }^{4}$ Malassezia furfur, T. asahii, Rhodotorula, Pichia anomala, C. albicans, C. lusitaniae, $C$. holmii, C. norvegensis, $C$. valida and $C$. dublinensis have been reported as emerging pathogenic yeasts in humans. ${ }^{4}$ Even yeasts such as $C$. utilis and C. lipolytica, which are considered to be environmental pollutants and have industrial importance, have been identified as agents of fungemia, onychomycosis and systemic disease. ${ }^{7}$ The results of the present study show that a large number of yeasts with evident pathogenicity were recovered from both the crop and cloaca and, in addition, $C$. albicans was the most frequently isolated yeast in dropping samples from public squares. Feral pigeons usually deposit their feces anywhere and nest in the most unlikely places such as air conditioning systems, trees and cornices. These locations could represent a point of dissemination of these pathogens to a large number of sites including hospitals, schools or any place where the prevalence of immunocompromised individuals may be high, as these populations are potentially more sensitive to the effects of such pathogens.

In conclusion, pigeons are an important source of yeasts which could be pathogenic in humans. Pigeon stool is the ideal environment for the replication of T. asahii, T. mucoides and even Candida species, and pigeons are important carriers and reservoirs of C. albicans and C. guilliermondii.

\section{Conflict of interest}

The authors declare no conflict of interest.

\section{Acknowledgements}

The authors would like to thank the pigeon breeders for their support during sample collection. We also acknowledge the technical assistance provided by Esther Licia Díaz Rodríguez.

\section{References}

1. Costa AK, Sidrim JJ, Cordeiro RA, Brilhante RS, Monteiro AJ, Rocha MF. Urban pigeons (Columba livia) as a potential source of pathogenic yeasts: a focus on antifungal susceptibility of Cryptococcus strains in Northeast Brazil. Mycopathologia. 2010;169:207-13.

2. Fanfair RN, Heslop O, Etienne K, Rainford L, Roy M, Gade L, et al. Trichosporon asahii among intensive care unit patients at a medical center in Jamaica. Infect Control Hosp Epidemiol. 2013:34:638-41.

3. Gallo MG, Cabeli P, Vidotto V. Presence of pathogenic yeasts in the feces of the semi-domesticated pigeon (Columba livia, Gmelin 1789, urban type) from the city of Turin. Parassitologia. 1989;31:207-12.

4. García-Martos P, Domínguez I, María P, García R, Mira J. Sensibilidad a antifúngicos de levaduras patógenas emergentes. Enferm Infecc Microbiol Clin. 2001;19:249-56. 
5. Gaskin HR, Wilson FB, Mather JP, Jacob JC, Garcia L. Patógenos portados por las aves transmisibles a los humanos, capaces de producir enfermedad en el hombre. Publicaciones del Departamento de Animal Science, del Servicio de Extensión Cooperativo de la Florida, del Instituto de Alimentos y Ciencias Agrícolas. Universidad de la Florida; 2001.

6. Hagen F, Khayhan K, Theelen B, Kolecka A, Polacheck I, Sionov E, et al. Recognition of seven species in the Cryptococcus gattii/Cryptococcus neoformans species complex. Fungal Genet Biol. 2015;78:16-48.

7. Hazen KC. New and emergent yeast pathogens. Clin Microbiol Rev. $1995 ; 10: 462-78$.

8. Hermoso de Mendoza M, Miranda A, Perea AJ, Arenas A, Poveda JB, Carranza J, et al. Criptococosis en paloma I. Frecuencia de portadores en buche en el área urbana de Córdoba. Rev Iberoam Micol. 1987;4:121-7.

9. Herrera ML, Vargas A, Campos M. Primer aislamiento clínico de Prototheca wickerhamii en Costa Rica. Rev Méd Hosp Nac Niños. 1998;33:1-2.

10. Hoog GS, Guarro J. Atlas of clinical fungi. 1a ed Reus - España: Baarn: Centralbureau voor Schimmelcultures; 1995.

11. Iacoviello V, DeGirolami P, Lucarini J, Sutker K, Williams ME, Wanke CA. Protothecosis in complicating prolonged endotracheal intubation: case report and literature review. Clin Infect Dis. 1992;15:959-67.

12. Kalkanci A, Dizbay M, Turan O, Fidan I, Yalçin B, Hirfanoglu I. Nosocomial transmission of Candida pelliculosa fungemia in a pediatric intensive care unit and review of the literature. Turk J Pediatr. 2010;52:42-9.

13. Koneman E, Allen SD, Janda WM, Schreckenberger PC, Winn WC. Diagnóstico Microbiológico. Buenos Aires: Panamericana; 1999.

14. Lin HC, Lin HY, Su BH, Ho MW, Ho CM, Lee CY, et al. Reporting an outbreak of Candida pelliculosa fungemia in a neonatal intensive care unit. J Microbiol Immunol Infect. 2013;46:456-62.

15. Maldonado LB, Sosa BA, Mizrachi R. Aislamiento de levaduras del Género Cryptococcus de excretas de palomas. Rev Soc Ven Microbiol. 2001;21:29-30.

16. Makinodan K, Yoshikawa M, Fukuoka A, Yoshimoto E, Tamaki S, Tomoda K, et al. A familial case of summer-type hypersensitivity pneumonitis possibly associated with bird breeder's lung diagnosed by bronchoalveolar lavage fluid. Nihon Kokyuki Gakkai Zasshi. 2005;43:696-9.

17. Mattsson R, Haemig PD, Olsen B. Feral pigeons as carriers of Cryptococcus laurentii, Cryptococcus uniguttulatus and Debaryomyces hansenii. Med Mycol. 1999;37:367-9.
18. Pasligh J, Radecke C, Fleischhacker M, Ruhnke M. Comparison of phenotypic methods for the identification of Candida dubliniensis. Rev Iberoam Micol. 2011;28:110-9.

19. Padhi M, Pattanaik S, Sahu S. Fungemia due to Trichosporon mucoides in a diabetes mellitus patient: a rare case report. Indian J Med Microbiol. 2014;32:72-4.

20. Ramirez R, Robertstad GW, Hutchison LR, Chavez J. Mycotic flora in the lower digestive tract of feral pigeons (Columba livia) in El Paso, Texas area. J Wildlife Dis. 1976;12:83-5.

21. Rosario I, Hermoso de Mendoza M, Déniz S, Soro G, Alamo I, Acosta B. Isolation of Cryptococcus species including C. neoformans from cloaca of pigeons. Mycoses. 2005;48:421-4.

22. Rosario I, Acosta B, Colom F. Pigeons and other birds as a reservoir for Cryptococcus spp. Rev Iberoam Micol. 2008;25:15-20.

23. Rosario I, Soro G, Déniz S, Ferrer O, Acosta F, Padilla D, et al. Presence of C. albidus, C. laurentii and C. uniguttulatus in crop and droppings of pigeon lofts (Columba livia). Mycopathologia. 2010;169:315-9.

24. Ruan SY, Chien JY, Hsueh PR. Invasive trichosporonosis caused by Trichosporon asahii and other unusual Trichosporon species at a medical center in Taiwan. Clin Infect Dis. 2009;49:11-7.

25. Runco R, Salim R. Fungemias por Pichia anomala en pacientes pediátricos inmunocomprometidos hospitalizados. Boletín Micológico. 2005;20: 103-8.

26. Sageerabanoo A, Oudeacoumar P, Udayashankar C. Onychomycosis due to Trichosporon mucoides. Indian J Dermatol Venerol Leprol. 2011;77:76-7.

27. Sota M, Ezpeleta C. Descripción de 165 episodios de fungemia de un estudio multicéntrico. Rev Iberoam Micol. 1999;16:30-5.

28. Vidotto V, Gallo MG. Study on the presence of yeasts in the feces of the rock pigeon (Columba livia, Gmelin 1789) from rural areas. Parassitologia. 1985;27:313-20.

29. Warren N, Kevin C. Candida, Cryptococcus, and other yeasts of medical importance. In: Murray P, Baron E, Pfaller M, et al., editors. Manual of clinical microbiology. 6th ed. Boston: ASM Press; 1995.

30. Woolrich A, Koestenblatt E, Don P. Cutaneus protothecosis and AIDS. J Am Acad Derm. 1994;31:920-4.

31. Wu Y, Du PC, Li WG, Lu JX. Identification and molecular analysis of pathogenic yeasts in droppings of domestic pigeons in Beijing, China. Mycopathologia. 2012;174:203-14. 